\title{
Bajang Ratu Temple as Idea Resource for Batik Motif Creation
}

\author{
Laksmi Kusuma Wardani ${ }^{1}$, Sriti Mayang Sari ${ }^{2}$, Ronald Hasudungan Irianto Sitinjak ${ }^{3}$ \\ 1,2,3 Interior Design Department, Faculty of Art and Design, Petra Christian University, Surabaya, Indonesia
}

laksmi@petra.ac.id

\begin{abstract}
Indonesian batik is rich in decorative motifs that are developing vastly to meet the current needs of the market. Batik has become a resource for creativity that supports the commodity of creative industries. This research is an experimental study on batik creations conducted through three stages: exploration, design and implementation. Bajang Ratu temple in Mojokerto, East Java Province in Indonesia has been used as the idea resource for creating batik. The objective of this research is to create new motifs that can be used for clothing or fashion. From the experiments conducted, several compositions of batik motifs have been produced such as those with motifs of animals, plants and man-made objects. Through this research, it is hoped that the results of the batik creations may increase the development of small to medium creative business units in Mojokerto
\end{abstract}

Key Words: Creation, Batik, Motif

\section{Candi Bajang Ratu Sebagai Sumber Gagasan Penciptaan Motif Batik}

Batik Indonesia memiliki kekayaan motif hias yang semakin berkembang dan tetap eksis menjawab kebutuhan masa kini. Batik menjadi sumber kreativitas yang mendukung perkembangan komoditas industri kreatif. Penelitian ini merupakan penelitian eksperimen penciptaan batik yang dilakukan secara ilmiah melalui tiga tahap, yakni eksplorasi, perancangan, dan perwujudan. Candi Bajang Ratu yang berada di Mojokerto, Jawa Timur Indonesia digunakan sebagai sumber gagasan penciptaann. Tujuan khusus yang ingin dicapai yakni terciptanya motif baru yang digunakan sebagai bahan kain sandang atau fesyen. Berdasarkan eksperimen yang telah dilakukan, dihasilkan karya batik dengan komposisi motif binatang, tumbuhan, dan benda buatan manusia. Hasil ciptaan diharapkan berpeluang untuk meningkatkan industri kreatif unit usaha kecil menengah masyarakat Mojokerto di Jawa Timur Indonesia.

Kata kunci: Creation, Motif, Batik

Peer review : 9 - 23 Agust 2018, Accepted : 3 September 2018 


\section{INTRODUCTION}

Indonesian Batik is rich in decorative motifs that are developing vastly to meet the current needs of the market. With its huge variety of motifs, the Indonesian batik has an important role to play in the development of fashion design. The aesthetic value of batik does not solely lie on its visual appearance but also in the charm of pattern complexity and harmonious colour combination. Furthermore, the batik in Indonesia possesses a symbolic beauty through the various arrangements of motifs and deep philosophical meanings as a result of cultural blending (Doellah, 2002). Batik is considered a piece of cloth made through traditional techniques (a piece of wastra). A wastra can be considered as batik if it contains two basic elements: dyeing technique using wax as the colour barrier and patterns with various motifs that has become the unique characteristic of batik (Doellah, 2002).

Motifs are important elements in the art of batik. They can be duplicated or varied in its repetition to make a pattern (Bates, 1960). The variation of motifs are needed to create a pattern of arrangement in batik. Variety is the counterweight to harmony, the other side of organization essential to unity (Ocvirk, 2006). The variation of batik motif is becoming richer and developing because of the wide sources of inspiration for it. Creative sources of inspiration in motif art include geometrical elements, natural elements, animal motifs, and human motifs (Djoemena, 1990; Meyer, 1957). The richness of batik motif can also be triggered by creativity based on artificial or man-made objects as the source of inspiration (Kerlogue, 2004). These motifs are results of the interactions between humans and their environment (Pihlström, 2002). In this research, the manmade objects of Bajang Ratu temple has been determined as the idea source in the creation of batik motif. Bajang Ratu temple is located in the village of Temon, Trowulan district, Mojokerto city, East Java Province in Indonesia. It was deemed to have functioned as an entrance to the holy buildings, constructed as a memorial of the death of King Jayanegara, the high ruler of the Majapahit kingdom in the past. Bajang Ratu was constructed like a padurak$s a$, or a gate- like structure that has a roof at the top of the structure. This construction functioned as a territorial boundary as well as a connecting gate between areas within the Majapahit palace complex. It is a historically and culturally interesting object for research and hence, it has been chosen as an idea resource for the creation of batik motifs in this research.

The objective of this research is to produce a novel creation of batik motifs for textiles and clothing, resourced from valuable historical and cultural artifacts of Indonesia. There is a rich variety of form in the ornaments on the temples, yet very little has been used as inspiration for batik motifs. Findings of this research may benefit the small to medium business units of creative industries of the local communities in Mojokerto, East Java. Besides that, the creations produced can also benefit art and design education as new composition materials for basic design courses, especially in the subject of developing local patterns. It is also hoped that the creations oriented on the development of creativity based on traditional cultural values would also assist the society in respecting, admiring and developing self-potentials in order to yield creative products through one's own local wisdom. Novel creativity could also be developed through creative human resources who are willing to innovate, as demonstrated in the objective of this research.

\section{LITERATURE REVIEWS}

From the results of data gathered through literature review, the batik in the past was used for many types of garment such as jarit (a long rectangular cloth with the dimensions $\pm 110 \mathrm{~cm} \mathrm{x}+260 \mathrm{~cm}$ ), sarung (a traditional garment used by the coastal communities of North Java that is rectangular in shape with the dimensions $\pm 220 \mathrm{~cm} \mathrm{x} \pm 110 \mathrm{~cm}$, with sewn corners), and kemben (a female top clothing with the dimensions $\pm 250 \mathrm{~cm} \mathrm{x} \pm 50 \mathrm{~cm}$ ). Besides those, batik was also used as a selendang (a traditional form of shawl with the same dimensions as the kemben, which can also be used as a gendhongan (a baby sling or a manual carrier for goods), iket, also known as udheng or destar (a traditional form of head band that was used by males with the dimensions $\pm 100 \mathrm{~cm} \times 100 \mathrm{~cm}$ ), and dodot, a ceremonial attire used according to keraton customs (Doellah, 2002; Kerlogue, 2004). The batiks of the past were used as spiritual symbols and hence they were worn by the kings and their families. Batik was considred a rare work of art; its uses were exclusive in nature and where limited to imperials and noble families for cermonial and spiritual occasions (Asa, 2014).

Eventually, batik developed into a functional object. Floral, leaf and branch motifs were combined (termed as sulur-suluran) and animals along with stylized motifs of plants and nature began to be used to beautify and enrich batik to become a material that is economic in nature, extending to use for ceremonial equipments, household objects and interior decorations (Asa, 2014). Hence, the function and essence of batik have undergone a shift in values and not all batik possesses a specific meaning. Batik, that was once considered a sacred object, can now also be a profane or secular object. It has developed into an artwork with economical purposes. Today, the use of batik as a clothing material is truly evident in the daily lives of people from all classes of society. While batik began to develop and spread to the society, and became the possession of the local communities, its functions have shifted to become 
art objects and daily needs for seeking higher economic values or material benefits (Asa, 2014).

\section{PROBLEM STATEMENTS}

In the field of fashion, the batik today has undergone a staggering development in terms of creative use: from party dresses for both adults and children to fashion accessories such as shoes, bags, sandals, hats and so on. Batik is even a compulsory attire for students and teachers in schools and universities, as well as for employees in both private and public companies in Indonesia. It has become an object of national pride by all classes of people in Indonesia. In time, batik has become one of the promising and prospective economic commodities to assist the social economy of the people. In this research, the batik motifs that have been created through the experiments conducted are specifically targetted for clothing material with motif arrangement compositions that accords with the needs of modern society.

Based on its style, the implementation or motif drawing technique of batik used the technique of stylization: a process involving an alteration of the original form from which it was inspired, into a new form, without disregarding the identity or specific characteristic of the original form, resulting in a novel creation. Another perceptive view regarding the process of stylization is: the styling of visual form to become a novel decorative form of artwork. The forms that were determined as sources of inspiration in this research are those found on the structure of the Bajang Ratu temple, including the ornamental decorations attached to it. Novel creations were formed through creativity stemming from original ideas that were developed through stylization of form in repetitive compositions.

\section{METHODOLOGY}

This research uses experimental methods in the creation of batik motifs, involving three stages of design process: exploration, design and implementation (Gustami, 2006; Gustami, 2007). In the exploration stage, literature reviews and field observations were conducted to gather data regarding the form and ornamental decorations of the Bajang Ratu temple in Mojokerto. The data were then classified according to the types of ornamental decorations which was then followed by the selection of ornaments can be used as sources of inspiration for developing batik motifs. In the design stage, the researchers conducted analysis through design experiments such as: 1) Creating design alternatives of batik motifs in the form of idea sketches, consisting of primary motifs, supporting motifs and filling motifs, usually termed as isen; 2) Developing design motifs and arranging the motifs in a composition to produce a pattern. The composition was created through repetitive parallel and diagonal arrangements as well as free arrangement of motifs; 3 ) Creating motifs for borders, corners and center points known as tumpal (traditional triangular-shaped motifs consisting of leaves and flowers) or side decorations that are usual for visual emphasis; 4) making models or prototype samples of the resulted motif compositions. The final design was then evaluated in terms of the quality of form, aesthetic value, material, production technique, function and socio-cultural aspects. In the implementation stage, the batik patterns were drawn on $2 \mathrm{~m}$ $\mathrm{x} 1.15 \mathrm{~m}$ of cloth.

\section{RESULTS AND DISCUSSION}

The creativity in creating batik motifs in this research stems from the idea of using the man-made object of Bajang Ratu temple, an object of historical value, as the source of batik motif creation. The creations were inspired by non-narrative ornaments of the Bajang Ratu temple structure, such as the ornament of surya Majapahit (an emblem of the Majapahit kingdom), traditional forms of giant creatures known as kala, lions, tumpal (triangular motifs with flower forms at the center), and sulur-suluran or lung-lungan (tendrils of flowers, leaves and branches). From the experiments conducted, batik motif creations were produced that function as clothing materials with motif compositions of animals, plants and man-made objects. The motif pattern arrangement adopt symmetrical, asymmetrical, diagonal and free form of arrangements with techniques of repetition, alternation, progression and continuity. Differences of repetitive motif forms triggers a sense of order. Harmony is achieved through repetition of the same or similar characteristics. Repetition helps in increasing unity in composition. The researchers and creators have derived specific names for the batik motifs produced as the results of this research, among which are Candi Bajang Ratu, Srengenge Muncar, Srengenge Mubeng, Sardula Kembar, Sinanjana Sinaroja, Mojo, Surya Puja, Lung Tumpal, based on their idea/concept source and forms resulted (Table 1).

\section{CONCLUSION}

The level of complexity in the experiments conducted to create batik motifs can be seen through the compositions developed based on the harmony and unity between the primary motif, secondary motif and filling motifs. The success of the creation of batik motifs that are visually pleasing do not only lie on a single motifs but on composition, arrangement and colour of the motifs, as well as the technique and production process conducted by batik craftsmen. The batik motif creations resulted from this research are evidence that temple ornaments can be possible sources of ideas for developing a wide variety of batik motifs. Through this research study, it is hoped that the new batik motif creations produced in this research may support the development of small to medium business units (UKM) and provide more opportunities for creative industries in Mojokerto, East Java, Indonesia. 
Table 1. Results of Batik Motif Creations

\begin{tabular}{|c|c|c|c|c|}
\hline \multirow{2}{*}{ Soerce of idea/concept } & \multirow{2}{*}{$\begin{array}{c}\text { Given name } \\
\text { of motif }\end{array}$} & \multicolumn{2}{|c|}{ Form of ereation } & \multirow{2}{*}{ Meaning of Motif } \\
\hline & & Batik motif & Variation of motif form & \\
\hline $\begin{array}{l}\text { Structural form of Bajang } \\
\text { Gatu Temple } \\
\text { the Majapahit palace }\end{array}$ & $\begin{array}{c}\text { Candli } \\
\text { Bajang Ratu }\end{array}$ & $\begin{array}{l}\text { Primary motif: Candi BajangRatu } \\
\text { Supporting motif: florals and } \\
\text { leaves }\end{array}$ & 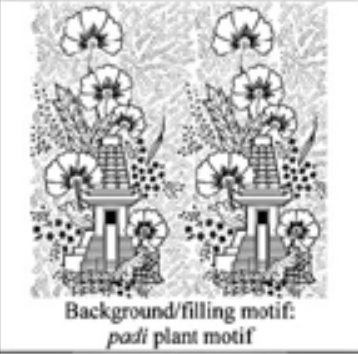 & $\begin{array}{l}\text { Symbol of unity of the society with } \\
\text { diverse religion. The gate represents } \\
\text { the entrance of the worldly life, } \\
\text { articulating the unity of the worldly } \\
\text { reality (jagad cilik) with the natural } \\
\text { reality (jagad gedhe). }\end{array}$ \\
\hline \multirow{3}{*}{$\begin{array}{l}\text { Emblem of the Majapahit } \\
\text { Kingdomm known as Suryo } \\
\text { Majappahit on the relief at } \\
\text { the crown of the Bajang } \\
\text { Ratu temple } \\
\text { This symbol can be found } \\
\text { on several parts of the } \\
\text { temple as well as cther or } \\
\text { other sites of Majapahit } \\
\text { buildings. Its form } \\
\text { resenbles the sun, and has } \\
8 \text { sides with a circular form } \\
\text { at the center. }\end{array}$} & $\begin{array}{l}\text { Srengenge } \\
\text { Murncar } \\
\text { (sunshine) }\end{array}$ & Primary motif: Sun & $\begin{array}{l}\text { Alternative of primary motif form: } \\
\text { combination of sun and radiating lines }\end{array}$ & $\begin{array}{l}\text { Symbol of sun, representing } \\
\text { blessings for bright rays shining on } \\
\text { all directions of the earth. }\end{array}$ \\
\hline & $\begin{array}{l}\text { Srengenge } \\
\text { Mubeng } \\
\text { (fevolving } \\
\text { sun) }\end{array}$ & $\begin{array}{l}\text { Primary motif: sun } \\
\text { Supporting motif: revolving fan } \\
\text { form }\end{array}$ & & $\begin{array}{l}\text { Symbol of sun, articulating } \\
\text { blessings of bright rays revolving } \\
\text { towards the earth. }\end{array}$ \\
\hline & Sarya Puja & $\begin{array}{l}\text { Primary motif: sun at the center } \\
\text { with florals surrounding it }\end{array}$ & 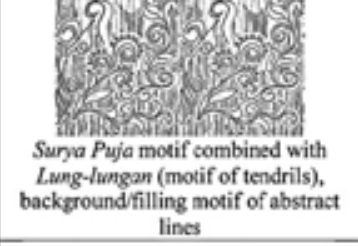 & $\begin{array}{l}\text { Symbol of puja, articulating praise } \\
\text { for the blessings of crops and the } \\
\text { sunlight spreading throagh the } \\
\text { earth. }\end{array}$ \\
\hline $\begin{array}{l}\text { A pair of confronting lions } \\
\text { found on the relief at the } \\
\text { crown of the Bajarg Ratu } \\
\text { temple }\end{array}$ & $\begin{array}{l}\text { Sardula } \\
\text { Kembar } \\
\text { (Twin lions) }\end{array}$ & $\begin{array}{l}\text { Primary motif: } \\
\text { Stylized form of a lion }\end{array}$ & $\begin{array}{c}\text { A pair of confronting lions } \\
\text { (Sandula Kembar) }\end{array}$ & $\begin{array}{l}\text { Symbol of the jungle king. } \\
\text { representing a prosperity that is } \\
\text { balanced and stable. }\end{array}$ \\
\hline $\begin{array}{l}\text { A single-eyed giant creature } \\
\text { known as Kala Eke Caksu } \\
\text { found at the top edge of the } \\
\text { crown of Bajang Ratu } \\
\text { temple }\end{array}$ & $\begin{array}{c}\text { Simanjana } \\
\text { Simaroja }\end{array}$ & $\begin{array}{l}\text { Primary motif: } \\
\text { Sylized form of kala eka caksu }\end{array}$ & Repetitive motif of Sincriana & $\begin{array}{l}\text { Symbol of mawas (alertness), } \\
\text { representing the human heart that } \\
\text { must always be alert in order to find } \\
\text { the bright path with the hope of } \\
\text { abundant blessings. }\end{array}$ \\
\hline $\begin{array}{l}\text { Daun Moja, a special tree } \\
\text { of Trowulan Mojokerto } \\
\text { (the capital city of the } \\
\text { Majapahit kingdom in the } \\
\text { past) }\end{array}$ & Mojo & $\begin{array}{l}\text { Q0 } \\
\text { Mojo leaf and fruit }\end{array}$ & $\begin{array}{c}\text { a } \\
\text { A collection of mojo leaves }\end{array}$ & $\begin{array}{l}\text { Symbol of the specialty dish of the } \\
\text { Majapahit Kingdom, articulating } \\
\text { that what looks beautiful does not } \\
\text { main it tastes as sweet. }\end{array}$ \\
\hline $\begin{array}{l}\text { Tumpal motif, which can be } \\
\text { found on Bentar and } \\
\text { Padurabsa temple, } \\
\text { commonly at the base of } \\
\text { the temples }\end{array}$ & Lung Timpal & $\begin{array}{l}\text { Side decoration: } \\
\text { Triangular forms (turmpal) with } \\
\text { flower motifs at the center. }\end{array}$ & $\begin{array}{l}\text { Tumpal motif combined with the } \\
\text { background motif of tendrils } \\
\text { (hens-lungan) }\end{array}$ & $\begin{array}{l}\text { Geometric omament with triargular } \\
\text { shapes, to be used as corner } \\
\text { decorations (pinggiran). }\end{array}$ \\
\hline
\end{tabular}

Copy right of motif design: Laksmi Kusuma Warcani, Ronald Hasudungan Irianto Sitinjak, and Sriti Mayarg Sari, 2016. 


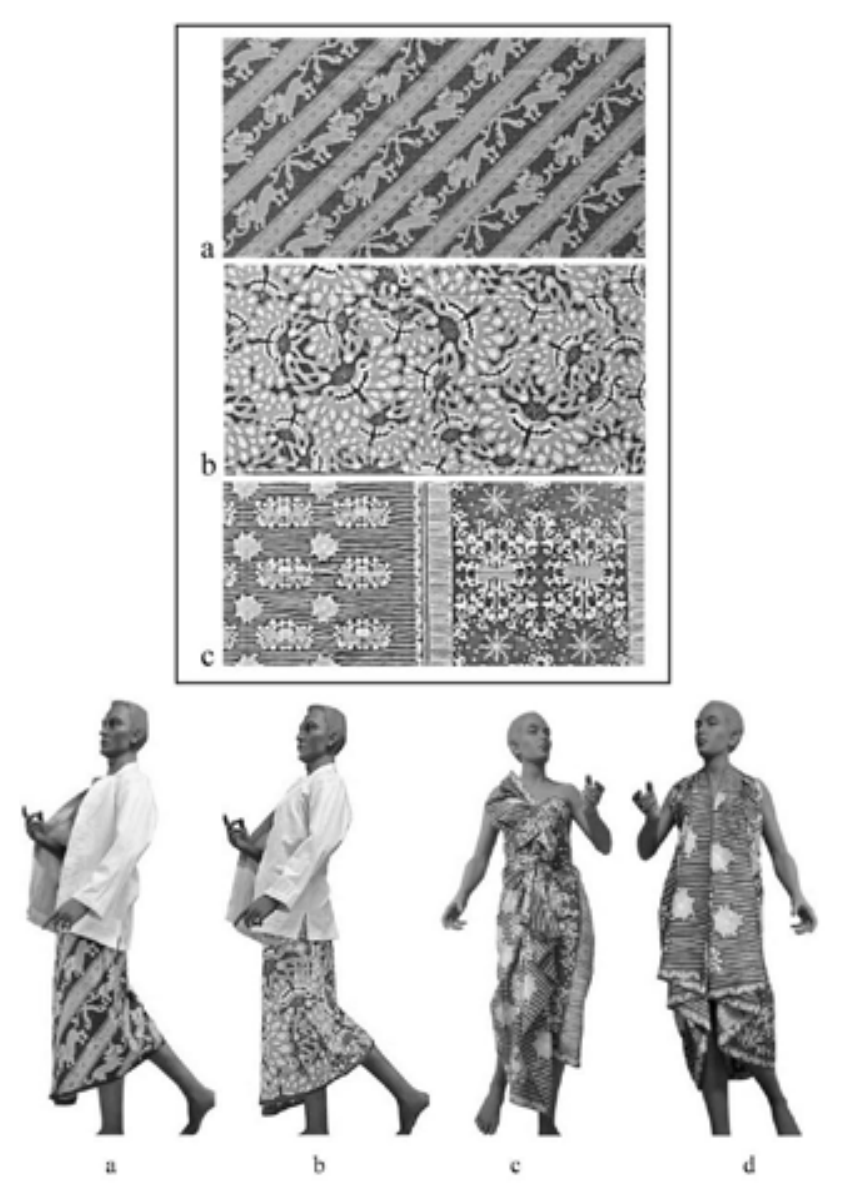

Figure 1. Variation of experimentations in the creation of batik motifs implemented in fashion clothing. Composition arrangements include diagonal, rotating, repetition and simultaneous (a \& b: Sardula Kembar motif, c \& d Surya Puja and Sardula Kembar composition motif)

(Photo and copy right: Laksmi Kusuma Wardani, Ronald Hasudungan Irianto Sitinjak, and Sriti Mayang Sari, 2016).

\section{ACKNOWLEDGEMENT}

This paper reported the public service activities financed by the Ministry of Research, Technology and Higher Education, Republic of Indonesia.

\section{REFERENCES}

H. Santosa Doellah. (2002). Batik Pengaruh Zaman dan Lingkungan. Surakarta: Danar Hadi. Kenneth F. Bates. (1960). Basic Design: Principles and Practice. New York: The World PublishingCompany.

Otto G. Ocvirk, Robert E.Stinson, Philip R. Wigg, Robert O.Bone, David L. Cayton. (2006). Art Fundamental: Theory and Practice, New York: McGraw-Hill.

N.S. Djoemena. (1990). Ungkapan Sehelai Batik, Its Mistery and Meaning. Jakarta: Djambatan Franz Sales Meyer. (1957). Handbook of Ornament. New York: Dover Publication, Inc.
Fiona Kerlogue. (2004). The Book of Batik. Singapore: Archipelago Press, 136-138.

Sami Pihlström. (2002). "Pragmatism, Art, and the Real World", in Action, Criticism, and Theory for Music Education. Vol.1, No.1, April, 1-30.

SP. Gustami. (2006). "Trilogi Keseimbangan Ide Dasar Penciptaan Kriya Seni: Untaian Metodologis, in Dewi Ruci: Jurnal Pengkajian dan Penciptaan Seni. Surakarta: Program Pendidikan Institut Seni Indonesia (ISI) Surakarta, Vol.4, No.1, 1-16.

SP. Gustami. (2007). Butir-Butir Mutiara Estetika Timur: Ide Dasar Penciptaan Seni Kriya Indonesia. Yogyakarta: Prasista.

Kusnin Asa. (2014). Mosaic of Indonesian Batik. Indonesia: Red \& White Publishing dan Media Group. 